\title{
Performance and Adaptability Evaluation of Improved Onion Varieties (Allium cepa L.) for Bulb Yield and Some Agronomic Traits
}

\author{
Awoke Ali Zeleke ${ }^{1, *}$, Demis Fikre Limeneh ${ }^{1}$, Dasta Tsagaye Galalcha ${ }^{1}$, Gizaw Wegayehu Tilahun ${ }^{1}$, \\ Nimona Fufa Hunde', Fekadu Gebretensay Mengistu ${ }^{2}$ \\ ${ }^{1}$ Kulumsa Agricultural Research Center, Ethiopian Institute of Agricultural Research, Assela, Ethiopia \\ ${ }^{2}$ Debre Zeit Agricultural Research Center, Ethiopian Institute of Agricultural Research, Debre Zeit, Ethiopia
}

Email address:

awokeali2014@gmail.com (A. A. Zeleke)

${ }^{*}$ Corresponding author

\section{To cite this article:}

Awoke Ali Zeleke, Demis Fikre Limeneh, Dasta Tsagaye Galalcha, Gizaw Wegayehu Tilahun, Nimona Fufa Hunde, Fekadu Gebretensay Mengistu. Performance and Adaptability Evaluation of Improved Onion Varieties (Allium cepa L.) for Bulb Yield and Some Agronomic Traits. American Journal of BioScience. Vol. 9, No. 3, 2021, pp. 105-109. doi: 10.11648/j.ajbio.20210903.15

Received: April 9, 2021; Accepted: June 10, 2021; Published: June 16, 2021

\begin{abstract}
Onion is one of the most important vegetable crops in the world including Ethiopia. The field experiment was conducted in Arsi zone at Kulumsa Agriculture Research Center and Ziway Dugda districts under irrigation condition. A total of five improved onion varieties were evaluated in Randomized Complete Block Design with three replications with the objectives of studying the performance and adaptability of improved onion varieties for bulb yield and yield related traits in 2017 during off season. The combined Analysis of variance (variety by location) revealed that significant difference between improved onion varieties for maturity date, marketable and unmarketable bulb yield tons per hectare, bulb length in centimeter, and bulb weight in gram was observed. But non-significant difference for plant height in centimeter, total bulb yield tons per hectare and average bulb diameter in centimeter were observed between improved onion varieties. Except variety Adama Red all the tested improved onion varieties (Melkam, Nafis, Nasik Red and Bombay Red) was well performed and adapted. These varieties were gave more than 40 marketable bulb yield $\mathrm{t} \mathrm{ha}^{-1}$. So those improved onion varieties were recommended for the study area and areas of similar agro- ecological zones under off season growing condition.
\end{abstract}

Keywords: Adaptability, Bulb, Improved, Variety, Vegetable, Yield

\section{Introduction}

The common bulb onion, Allium cepa $\mathrm{L} .(2 \mathrm{n}=2 \mathrm{x}=16)$ is the most widely cultivated species of the genus Allium and the family Amaryllidaceae/Alliaceae. It is widely grown herbaceous biennial vegetable crop with cross pollinated and monocotyledonous behavior having diploid chromosomes number [1]. Globally it is one of the most important vegetable crops and its demand increasing worldwide [2].

It is a recently introduced bulb crop in the agriculture community of Ethiopia and it is rapidly becoming a popular vegetable among producers and consumers. It is more widely grown in Ethiopia for local consumption and for flower export [3]. In Ethiopia, onion can grow between 500- 2400 meter above sea level, but the best growing altitude so far known is between $700-1800 \mathrm{~m}$ [4]. It is grown under wide range of climatic conditions but it succeeds best in mild seasons without great extremes of heat or cold or excessive rainfall. Optimum temperatures of $18-24^{\circ} \mathrm{C}$ day and $10-$ $12^{\circ} \mathrm{C}$ nights are ideal for bulb production. Onion can grow in all types of soils. Highest yield was obtained from freely drained friable loam soil with $\mathrm{P}^{\mathrm{H}}$ of 6-6.8 [3].

Onion has been grown mainly as food sources and used as cousins and value addition for different dishes. In Ethiopia, the consumption of the crop is very important in the food seasoning and in daily stews as well as in different vegetable food preparation uses [5]. Also, the chemical flavonoids, anthocyanins, fructo-oligosaccharides and organo-sulphur compounds found in the onion is considered as medicinal and health benefits to fight different diseases including cancer, 
heart and diabetic diseases [6].

In Ethiopia, the area under onion production is increasing from time to time mainly due to its high profitability per unit area and ease of production, and the increases in small scale irrigation areas. The crop is produced both under rainfed in the meher season and under irrigation in the off season. In many areas of Ethiopia, the off season crop (under irrigation) constitutes much of the area under onion production [7].

According to [8] report a total of $99,968,016$ tons of onion is produced worldwide. China is the largest onion producer country in the world with 24,966,366 tons production volume per year. In Africa, Egypt is the top onion producer country with 3,081,047 tons production and, Ethiopia ranked in $9^{\text {th }}$. In Ethiopia, during 2019/20 growing season 734,921 small house holders are engaged in onion production. The total area allocated to onion has reached $36,373.48$ ha; total production of $273,858.986$ tons and the national average productivity is 7.53 tons $\mathrm{ha}^{-1}$ as compared with the world average productivity 19.25 tons $^{-1} a^{-1}[8,9]$. The main reason for this lower productivity of the crop is most probably due to lack of improved onion varieties/seeds, inappropriate agronomic practices such as (inappropriate fertilizer rate, inter and intra row spacing), diseases and insect pests, high cost of agricultural chemicals including fungicides, insecticides, and a little-given attention to the crop production and poor extension system $[3,5,7,10-13]$. The Successful onion production depends on the selection of varieties that are adapted to different climatic conditions imposed by specific environment [14]. There is no systematic study has been conducted to assess the stability and adaptability of onion for cultivation in the study area. Hence, the present experiment was conducted to study the performance evaluation and adaptability of some improved onion varieties for cultivation at Kulumsa and Ziway Dugda districts.

\section{Materials and Methods}

\subsection{Description of the Study Area}

The experiment was conducted at Kulumsa Agricultural Research Center and Abura, Arsi Zone, Oromia, Ethiopia under irrigation condition in 2017. Kulumsa Agricultural Research Center is found in Arsi, Zone Oromia Regional State, Ethiopia, is located $175 \mathrm{~km}$ South East of Addis Ababa on the road from Adama to Asella. The geographical location of Kulumsa is $8^{0} 01$ ' $10^{\prime \prime} \mathrm{N}$ latitude and $39^{\circ} 09^{\prime} 13$ " $\mathrm{E}$ longitude and at an altitude of 2200 meter above sea level. The agro-ecology of the area is characterized by an average annual rain-fall of $850 \mathrm{~mm}$, with short rain between March and April and long rain between June and September, and with annual mean minimum and maximum temperatures of $23.1{ }^{\circ} \mathrm{C}$ and $7.9^{\circ} \mathrm{C}$ respectively. The soil types of the area is clay and silt loam with $\mathrm{pH}$ of 5.6 [15]. The second experimental location was Ziway Dugda. It is one of the Woreda in Arsi Zone, Oromia Region of Ethiopia, far away from $40 \mathrm{~km}$ North West of Assela town (the capital city of Arsi Zone). It is located $7^{0} 55^{\prime} 59 \mathrm{~N}$ latitude and $38^{\circ} 43^{\prime} 0^{\prime \prime} \mathrm{E}$ longitudes with an altitude of 1687 meter above sea level. The maximum and minimum temperature was 14.8 and $25^{\circ} \mathrm{C}$ respectively with annual rain fall 650 to $800 \mathrm{~mm}$. The soil type of the area was sandy loam.

\subsection{Experimental Materials, Design and Procedure}

A total of five improved onion varieties were introduced from Melkasa Agricultural Research Center/MARC used (Table 1). The varieties were arranged in Randomized Complete Block Design (RCBD) with three replications and each gross plot size was $2.4 \mathrm{~m} \times 3 \mathrm{~m}=7.2 \mathrm{~m}^{2}$ consisting of four rows, which accommodated 60 seedlings per rows. The net plot size is $1.8 \mathrm{~m} \times 2.9 \mathrm{~m}^{2}=5.22 \mathrm{~m}^{2}$. The spacing between rows, ridges and plants were $40 \mathrm{~cm}, 20 \mathrm{~cm}$, and 5 $\mathrm{cm}$ respectively. The spacing between plots and adjacent replications were $1 \mathrm{~m}$ and $1.5 \mathrm{~m}$, respectively. The two middle rows were used for data collection. Fertilizer application was made as per the specific recommendation for the location, in which DAP (Di Ammonium Phosphate) as a source of phosphorus was applied at a rate of $150 \mathrm{~kg} \mathrm{ha}^{-1}$ and Urea as a source of nitrogen was applied at rate of $100 \mathrm{~kg} \mathrm{ha}^{-}$ 1. DAP was applied once during transplanting period in the rows, while urea was applied in split application half at during transplanting period and half at 45 days after first application as a side dress application. All other agronomic practices such as weeding, cultivation and spraying chemicals were kept uniform for all treatments in each plot.

Table 1. List of studied onion varieties and their sources.

\begin{tabular}{ll}
\hline Varieties & Year of release \\
\hline Nafis & 2010 \\
Bombay Red & 2004 \\
Nasik Red & 2004 \\
Adama Red & - \\
Melkam & $1997 / 98$ \\
\hline
\end{tabular}

Sources: All improved varieties was released by MARC/EIAR

\subsection{Data Collection}

Days to maturity: the number of days elapsed from the time of planting up to the time when $80 \%$ of plants in the plot became yellow, dry and collapsed at the neck was counted and the mean values were computed and used for further analysis [16].

Plant height in $\mathrm{cm}$ : The height of ten plants in each plot was measured in centimeter from the ground surface to the tip of the longest leaf and averaged to get the mean plant height.

Marketable bulb yield $\left(\mathrm{tha}^{-1}\right)$ : Bulbs which were free of mechanical, disease and insect pest damages, uniform in color and medium to large in size $(20-160 \mathrm{~g})$ were considered as marketable. The weight of such bulbs obtained from the net plot area of each plot was measured in kilogram using scaled balance and expressed as ton per hectare [3].

Unmarketable bulb yield $\left(\mathrm{t} \mathrm{ha}^{-1}\right)$ : Harvested bulbs which were under as well as oversized $(<20 \mathrm{~g}$ and $>160 \mathrm{~g})$, misshaped, decayed, discolored, diseased and physiologically 
disordered were considered as unmarketable according to [3]. The weight of such bulbs obtained from the net plot area of each plot was measured in kilogram using scaled balance and expressed as ton per hectare.

Total bulb yield $\left(\mathrm{t} \mathrm{ha}^{-1}\right)$ : Total yield of onion was obtained by adding marketable and unmarketable bulb yields and expressed as ton per ha [16].

Bulb weight $(\mathrm{g})$ : The mean bulb weight of ten randomly selected bulbs at harvest was computed and used for further analysis [16].

Bulb length $(\mathrm{cm})$ : The lengths of ten randomly selected bulbs per plot were measured from the bottom to the top using caliper and the mean value was computed for further analysis [16].

Bulb diameter $(\mathrm{cm})$ : The mean size of the bulb at harvest was computed by measuring the diameters at the middle of ten randomly selected bulbs in each plot using caliper [3].

\subsection{Data Analysis}

The data was subjected to analysis of variance (ANOVA) using General Linear Model (GLM) model in SAS software version 9.0 statistical packages. Least Significance Difference (LSD) was used to compare means at 5\% and $1 \%$ level of significance.

\section{Results and Discussion}

The combined Analysis of variance (ANOVA) showed that significant difference between improved onion varieties in terms of their maturity date, both marketable and unmarketable bulb yield in $\mathrm{t} \mathrm{ha}^{-1}$, bulb length in $\mathrm{cm}$, and bulb weight in $g$ was observed. But, non-significant difference was observed between onion varieties for plant height in $\mathrm{cm}$, total bulb yield in $\mathrm{t} \mathrm{ha}^{-1}$ and average bulb diameter in $\mathrm{cm}$ (Table 2). Many authors reported significant variation between improved onion varieties for both agronomic and bulb yield. According to [17, 18] report significant variation was observed between improved onion varieties for marketable and unmarketable bulb yield $\mathrm{t} \mathrm{ha}^{-1}$. Similarly [12] stated that significant difference between improved onion varieties was observed for marketable bulb yield. Additionally [12, 17-19] also stated non-significant difference for bulb size/diameter was reported among improved onion varieties. Nonsignificant difference for total bulb yield among onion varieties was reported by [19].

\subsection{Maturity Date}

Improved onion variety Melkam matured earlier (101.83 days) to attain $80 \%$ maturity, while variety Nafis matured later (110.67 days) followed by Bombay Red (107.83 days), Nasik Red (106.0 days) and Adama Red (105.67 days). The variation of maturity date between improved onion varieties might be due to their inherent genetic difference. Similarly [10] and [12] reported that significant difference among onion varieties for maturity date.

\subsection{Plant Height in $\mathrm{cm}$}

Plant height in $\mathrm{cm}$ raged from $56.54 \mathrm{~cm}$ to $65.24 \mathrm{~cm}$ with a population mean of $60.35 \mathrm{~cm}$. The longest plant height was recorded from variety Nafis $(65.24 \mathrm{~cm})$ while the shortest from variety Melkam $(56.54 \mathrm{~cm})$. The presence of significant difference between improved onion varieties in plant height was reported by [12].

\subsection{Marketable, Unmarketable and Total Bulb Yield tha ${ }^{-1}$}

The highest marketable bulb yield was obtained from variety Melkam (44.54 $\left.\mathrm{t} \mathrm{ha}^{-1}\right)$ followed by Nafis (44.44 $\left.\mathrm{t} \mathrm{ha}^{-1}\right)$, Nasik Red (43.42 $\left.\mathrm{tha}^{-1}\right)$ and Bombay Red (42.02 $\left.\mathrm{tha}^{-1}\right)$ while the lowest marketable bulb yield was obtained from variety Adama Red (36.11 t ha ${ }^{-1}$ ). The difference due to bulb yield might be genetic variation among onion varieties. In agreement with the present result [10] reported higher marketable bulb yield was obtained from variety Melkam (34.36 $\left.\mathrm{t} \mathrm{ha}^{-1}\right)$ and lower from Adama Red $\left(28.45 \mathrm{t} \mathrm{ha}^{-1}\right)$. Similar [13] also reported that the marketable lower bulb yield was obtained on variety Adama Red. The two Varieties (Bombay Red and Melkam) gave maximum unmarketable bulb yield (4.10 and $3.64 \mathrm{t} \mathrm{ha}^{-1}$ respectively) and variety Adama Red gave minimum unmarketable bulb yield $(0.86 \mathrm{t}$ $\left.\mathrm{ha}^{-1}\right)$. Except onion variety Adama Red the other four varieties gave more than 40 tons total bulb yield $\mathrm{tha}^{-1}$. The higher total bulb yield was recorded from variety Melkam (48.18) and the lower total bulb yield was obtained from variety Adama Red (36.97) (Table 3). Significant difference between improved onion varieties for marketable bulb yield was reported by [12]. The present result is in agreement with [10]. According to [18] report lower bulb yield was measured from Adama Red (3.45 $\mathrm{t} \mathrm{ha}^{-1}$ ). Similarly [17] reported that the lowest marketable and total bulb yield was measured from variety Adama Red (15.82 and $19.22 \mathrm{t} \mathrm{ha}^{-1}$ respectively). Additionally [17] also stated that the higher and lower unmarketable bulb yield was recorded from variety Bombay Red and Adama Red (8.98 and $0.36 \mathrm{t} \mathrm{ha}^{-1}$ ).

\subsection{Average Bulb Length (cm), Average Bulb Diameter (cm) and Average Bulb Weight (g)}

Bulb length, bulb diameter and bulb weight was ranged from 5.23 to $5.70 \mathrm{~cm}, 5.18$ to $5.67 \mathrm{~cm}$ and 69.28 to $89.68 \mathrm{~g}$ respectively. The Largest bulb length was measured from variety Bombay Red $(5.70 \mathrm{~cm})$ and the shorter bulb length was recorded from variety Melkam $(5.23 \mathrm{~cm})$. The wider bulb diameter was measured from variety Bombay Red (5.67 $\mathrm{cm})$ while the narrow bulb diameter was obtained from variety Adama Red $(5.18 \mathrm{~cm})$ followed by variety Melkam $(5.32 \mathrm{~cm})$ (Table 3$)$. The present result is similar with [17] reports minimum bulb diameter in $\mathrm{cm}$ was measured from variety Adama Red $(5.08 \mathrm{~cm})$. Similarly [13] reported that the largest bulb diameter was recorded for variety Bombay Red at Fogera districts.

Variety Nafis weighted maximum bulb weight (89.68 g) followed by Bombay Red (84.72 g), while variety Adama Red weighted minimum bulb weight (69.28) (Table 3). 
Table 2. Mean Square for yield and yield components of improved onion varieties at Kulumsa and Ziway Dugda in 2017.

\begin{tabular}{llllllllll}
\hline Traits & Rep. (2) & Location (1) & Variety (4) & Location X Variety (4) & Error (18) & Mean & CV & R $^{2}$ & LSD \\
\hline DM & 3.10 & $38.53^{* *}$ & 62.72 & $12.45^{*}$ & 3.88 & 106.40 & 1.85 & 0.83 & 2.39 \\
PH & 23.39 & $3478.97 \mathrm{~ns}$ & 62.13 & $14.11 \mathrm{~ns}$ & 32.07 & 60.35 & 9.38 & 0.87 & 6.87 \\
MBYHA & 9.33 & $4223.08^{*}$ & 73.61 & $57.20^{*}$ & 17.66 & 42.11 & 9.98 & 0.94 & 5.20 \\
UBYHA & 0.80 & $13.9 .76^{* *}$ & 14.54 & $14.92^{* *}$ & 0.99 & 2.18 & 45.55 & 0.94 & 1.21 \\
TBYHA & 5.36 & $2826.32^{* *}$ & 110.53 & $24.69 \mathrm{~ns}$ & 16.61 & 44.29 & 9.20 & 0.92 & 4.94 \\
BL & 0.38 & $5.76 \mathrm{~ns}$ & 0.21 & $0.58^{*}$ & 0.73 & 5.53 & 7.54 & 0.76 & 0.51 \\
BD & 0.08 & $6.84 \mathrm{~ns}$ & 0.27 & $0.31 \mathrm{~ns}$ & 0.11 & 5.44 & 6.20 & 0.82 & 0.41 \\
BW & 9.85 & $3178.41^{* *}$ & 382.41 & $182.64^{*}$ & 52.66 & 79.28 & 9.15 & 0.85 & 8.80 \\
\hline
\end{tabular}

*Significant at $5 \%$ level of significance, ** Significant at $1 \%$ level of significance, ns- non- significant, DM-days to maturity, PH-plant height in cm, MBYHAMarketable bulb Yield ( $t / h a)$, UBYHA-Unmarketable bulb Yield ( $/$ ha), TBYHA=Total bulb Yield ( $/ / h a), C V=$ Coefficient of variance, LSD-Least Significant Difference, $\mathrm{R}^{2}$ - coefficient of determination, BL- average bulb length in $\mathrm{cm}$, BD- average bulb diameter in $\mathrm{cm}$, BW- average bulb weight in $\mathrm{g}$

Table 3. Combined mean performance of improved onion varieties for their bulb yield and yield related traits at Kulumsa and Ziway Dugda in 2017.

\begin{tabular}{lllllllll}
\hline Varieties & DM & PH & MBYHA & UBYHA & TBYHA & BL & BD & BW \\
\hline Nafis & $110.67^{\mathrm{a}}$ & $65.24^{\mathrm{a}}$ & $44.44^{\mathrm{a}}$ & $1.07^{\mathrm{b}}$ & $45.51^{\mathrm{a}}$ & $5.67^{\mathrm{a}}$ & $5.64^{\mathrm{a}}$ & $89.68^{\mathrm{a}}$ \\
Bombay Red & $107.83^{\mathrm{b}}$ & $59.53^{\mathrm{ab}}$ & $42.02^{\mathrm{a}}$ & $4.10^{\mathrm{a}}$ & $46.12^{\mathrm{a}}$ & $5.70^{\mathrm{a}}$ & $5.67^{\mathrm{a}}$ & $84.72^{\mathrm{ab}}$ \\
Nasik Red & $106.0^{\mathrm{b}}$ & $61.29^{\mathrm{ab}}$ & $43.42 \mathrm{a}$ & $1.24^{\mathrm{b}}$ & $44.66^{\mathrm{a}}$ & $5.52^{\mathrm{a}}$ & $5.38^{\mathrm{a}}$ & $76.09^{\mathrm{bc}}$ \\
Adama Red & $105.67^{\mathrm{b}}$ & $59.53^{\mathrm{ab}}$ & $36.11^{\mathrm{b}}$ & $0.86^{\mathrm{b}}$ & $36.97^{\mathrm{b}}$ & $5.51^{\mathrm{a}}$ & $5.18^{\mathrm{a}}$ & $69.28^{\mathrm{c}}$ \\
Melkam & $101.83^{\mathrm{c}}$ & $56.54^{\mathrm{b}}$ & $44.54^{\mathrm{a}}$ & $3.64^{\mathrm{a}}$ & $48.18^{\mathrm{a}}$ & $5.23^{\mathrm{a}}$ & $5.32^{\mathrm{a}}$ & $76.64^{\mathrm{bc}}$ \\
\hline
\end{tabular}

DM-days to maturity, PH-plant height in cm, MBYHA- Marketable bulb yield ( $\mathrm{t} / \mathrm{ha}$ ), UBYHA-Unmarketable bulb yield ( $\mathrm{t} / \mathrm{ha}$ ), TBYHA-Total bulb yield $(\mathrm{t} / \mathrm{ha}), \mathrm{BL}$ - average bulb length in $\mathrm{cm}$, BD- average bulb diameter in $\mathrm{cm}$, BW- average bulb weight in $\mathrm{g}$

\section{Conclusion}

The study results showed significant variation between improved onion varieties for some agronomic, and bulb yield and bulb quality traits. All improved onion varieties except Adama Red gave more than 40 marketable bulb yield $\mathrm{t} \mathrm{ha}^{-1}$. The highest marketable yield and total bulb yield was obtained from variety Melkam (44.54 and $48.18 \mathrm{t} \mathrm{ha}^{-1}$ ) and the lowest from variety Adama Red (36.11 and $36.97 \mathrm{t} \mathrm{ha}^{-1}$ respectively). From this it concludes those varieties were popularized and demonstrated to farmers for onion production in Kulumsa and Ziway Dugda districts and similar agro ecological areas.

\section{Acknowledgements}

The authors would like to express their special gratitude and warm appreciation to Ethiopian Institute of Agricultural Research (EIAR) and Kulumsa Agricultural Research Center (KARC) for fully financing the study.

\section{References}

[1] M. J. Bassett, Breeding vegetable crops. 1986. West Port. Connecticut: AVI Publishing Co. Inc.

[2] Bindu, B. and Bindu, P. 2015. Performance evaluation of onion (Allium Cepa L. Var. Cepa) varieties for their suitability in kollam district.

[3] Lemma Dessalegne and Shemelis Allilu. 2003. Research Experiences in Onion production. EARO. 52p.

[4] Lemma Dessalegne and E. Herath. 1994. Agronomic studies on Allium. In: Herath, E and Lemma Dessalegne. eds. Proceeding of the Second National Horticultural Workshop of Ethiopia PP. 139-146.

[5] Muluneh Bekele E., Mosissa Chewaka A. and Bikila Ollika F. 2019. Major onion (Allium cepa L.) production challenges in Ethiopia: A review. Journal of Biology, Agriculture and Healthcare, 9 (7).

[6] Goldman IL. 2011. Molecular breeding of healthy vegetables. EMBO Rep 12: 96-102.

[7] Fikre Mulugeta and Olani Nikus. 2010. Onion Seed Production Techniques A Manual for Extension Agents and Seed Producers pp. 8-9. Assela, Ethiopia.

[8] FAO-STAT. 2019/20. Countries - Select All; Regions - World + (Total); Elements - Production Quantity; Items - onions; years- 2019.

[9] CSA (Central Statistical Agency). 2019/20. Agricultural Sample Survey Report on Area and Production (Private Peasant Holdings Meher Season. Central Statistical Agency of Ethiopia, Statistical Bulletin.

[10] Yemane Kahsay, Derbew Belew and Fetien Aabay. 2014. Effects of intra-row spacing on plant growth and yield of onion varieties (Allium cepa L.) at Aksum, Northern Ethiopia. African Journal of Agricultural Research, 9 (10), pp. 931-940.

[11] Melkamu Alemayehu, Fentahun Tesfa, Solomon Bizuayehu and Belayneh Ayele. 2015. Amhara Region Horticultural Development Strategy 2015 - 2020.

[12] Gebremedhn Gebretsadkan, Yohanes Gebremicael, Kiros Asgele, Eyasu Abebe, Woldegerima Gebrelibanos and Yrgalem Tsehaye. 2018. Enhancing Productivity and Production of Onion (Allium cepa L.) Through the use of Improved Varieties at North Western Zoze of Tigray, Ethiopia. International Journal of Environment, Agriculture and Biotechnology, 3 (3). 
[13] Dessie Getahun, Mulat Getaneh, Birhanu Habte and Tesfa Binalfew. 2020. Participatory Onion Variety Evaluation at Fogera District of South Gondar Zone, Ethiopia. Journal of Plant Genetics and Breeding. an open access journal.

[14] Pandey U. B. 1989. Onion (Allium cepa L.) varietal trial, Indian Hort., 33: 58-62.

[15] Abayneh Esays, Demeke Tafase, Gebeyehu Belay and Kebede Agazegn. 2003. Soil of Kulumsa Agricultural Research Center. National Soil Research Center (NSRC), Soil survey and land evaluation, Technical Paper. No. 76.

[16] Guesh Tekle. 2015. Growth, Yield, and Quality of Onion (Allium Cepa L.) As Influenced By Intra-Row Spacing and Nitrogen Fertilizer Levels in Central Zone of Tigray, Northern Ethiopia.
[17] Geremew Awas, Teshome Abdisa, Kasaye Tolesa and Amenti Chali. 2010. Effect of intra-row spacing on yield of three onion (Allium cepa L.) varieties at Adami Tulu agricultural research center (mid rift valley of Ethiopia).

[18] Neim Semman, Getachew Etana and Tewodros Mulualem. 2019. Adaptability and yield performance evaluation of onion (Allium cepa L.) varieties in Jimma zone, Southwestern Ethiopia.

[19] Addis Shiferaw. 2020. Onion (Allium cepa) Varieties Evaluation at Miyo District of Borana Lowland. Acta Scientific Agriculture (ISSN: 2581-365 x). Volume 4 Issue 3 March 2020. DOI: 10.31080/ASAG.2020.04.080.1 